
$\$$ Research Square
Preprints are preliminary reports that have not undergone peer review.
They should not be considered conclusive, used to inform clinical practice, or referenced by the media as validated information.

\title{
Disentangling causes of the dieback of littoral stands in an overloaded water-bird reserve: roles of eutrophication, fish and geese
}

\section{Richard Svidenský}

University of South Bohemia Faculty of Agriculture: Jihoceska Univerzita v Ceskych Budejovicich Zemedelska Fakulta

\section{Andrea Kučerová}

Institute of Botany Czech Academy of Sciences: Botanicky Ustav Akademie Ved Ceske Republiky

Hana Čižková ( $\square$ hcizkova@zf.jcu.cz)

University of South Bohemia Faculty of Agriculture: Jihoceska Univerzita v Ceskych Budejovicich

Zemedelska Fakulta https://orcid.org/0000-0001-8692-3903

\section{Research Article}

Keywords: carp, geese, grazing damage, fishpond, sediment, Typha angustifolia

Posted Date: April 14th, 2021

DOI: https://doi.org/10.21203/rs.3.rs-380196/v1

License: (c) (i) This work is licensed under a Creative Commons Attribution 4.0 International License. Read Full License 


\section{Abstract}

European fishponds used for semi-intensive fish production can serve for refuges of water birds if the fish stocks are limited but the effects of other ecological factors on the ecosystem stability are seldom considered. The aim of this study is to elucidate causes of a marked decline of littoral stands dominated with Typha angustifolia in a hypertrophic fishpond forming a part of a valuable water-bird reserve. Field investigation and two experiments were conducted in order to separate the effects of mineral nutrient availability, redox condition, fish and geese. The physico-chemical characteristics of water and sediments confirmed hypertrophic conditions in the fishpond but a follow-up mesocosm experiment did not prove a negative effect of the sediment quality on the plant growth. On the other hand, a field enclosure experiment showed a significant negative effect on shoot density, which was attributed to grazing by geese. An additional damage to plant belowground parts was ascribed to large carp individuals, albeit in small numbers. The study points to a conservation dilemma caused by large numbers of geese destroying littoral stands in a fishpond nature reserve, which then looses its nesting function for other water-bird species.

\section{Introduction}

European fishponds represent important refuges of aquatic and wetland organisms in intensively used agricultural landscapes (IUCN 1997). They are shallow water bodies of various sizes, with an area ranging from several hectares to more than $1 \mathrm{~km}^{2}$. Many have well developed littoral belts which provide breeding sites for water birds including rare ones (e.g. Švažas and Stanevičius 1998; Janda and Ševčík 2002; Polak 2007; Gergely et al. 2009; Nieoczym 2010; Flis and Gwiazda 2018). Large fishponds or their systems also serve water birds as staging area during migration and wintering season (Miklín and Macháček 2016). Fishponds considered important for biodiversity have therefore been declared nature reserves according to national legislations, special protected areas according to the EU Directive No. 2009/147/EC (Birds Directive) or Wetlands of International Importance according to the Ramsar Convention.

Although European fishponds resemble natural shallow lakes in many aspects, their ecological functioning is largely determined by the purposeful rearing of fish, mainly cyprinids (Kestemont 1995, Pechar 2000, Schlumberger and Girard 2013). The intensity of fish production is promoted by manuring, liming and fish feeding, which in turn increase nutrient availability in the water column and promote accumulation of nutrient rich organic sediments on the bottom (Baxa et al. 2019). Large fish stocks control the food chains in the water column and at the bottom by feeding on large zooplankton and benthos. This results in steep vertical gradients of oxygen content, $\mathrm{pH}$, chlorophyll content and light penetration in summer (Bíró 1995, Potužák et al. 2007, Weber and Brown 2009).

In addition to the open water body, littoral stands, formed by species such as the common reed (Phragmites australis) or cattails (Typha spp.), are required by many species of water birds. They use them as shelter, source of material for building nests and also feed on plant biomass and/or large 
populations of invertebrates and fish fry that inhabit the littoral stands. On the other hand, some species can destroy the stands if they occur there in high densities. This has been documented both for birds (Bakker et al. 2018) and fish (Crivelli 1983). In addition, the size and stability of the littoral stands can be reduced by many other factors such as floods, high and stabilized water levels (Ostendorp 1989), eutrophication (van der Putten 1997, Č́ž́ková et al. 1999), toxic substances in the sediment (Armstrong et al. 1996, Armstrong and Armstrong 2001) and, finally, mechanical damage caused by human activities.

All of these factors can occur in fishponds and many of them are closely related to the fishpond management (Hejný et al. 2002; Francová et al. 2019a). In spite of the importance of both the open water body and the littoral stands for water birds, ecosystem studies looking at the relationships between various fishpond components are scarce. Several extensive studies assess the relationship between the fishpond management and biodiversity (Broyer and Calenge 2010; Broyer and Curtet 2012, Francová et al. $2019 b)$ but they do not specifically deal with the stability of the littoral stands. In addition, factors affecting the dynamics of littoral stands have almost exclusively been studied on Phragmites australis (cf. references in the previous paragraph), while knowledge on Typha species is still scarce.

In order to cover this gap, this paper presents an ecosystem study of a hypertrophic fishpond, part of a valuable water bird reserve, in which the littoral stands dominated with Typha angustifolia markedly declined during a decade between 2004 and 2013. The study, lasting from 2013 to 2016, had the following specific aims:

1. to document the extent of the decline and the condition of the remaining stands ;

2. to assess differences in the physico-chemical characteristic of water and sediments between dense (compact), sparse (declining) and already dead littoral stands, respectively;

3. to assess the effects of the anaerobic fishpond sediment on the plant growth and root health in a mesocosm cultivation experiment;

4. to test for a potential destruction of the stands by biota in a field enclosure experiment.

\section{Materials And Methods}

\subsection{Site description}

The study site was Bažina fishpond, part of the fishpond system Vrbenské rybníky (49.0092322 N, $14.4393331 \mathrm{E})$ near the city of České Budějovice, Czech Republic. The Vrbenské rybníky (Vrbenské fishponds) are a system of shallow water bodies used for rearing of fish, mainly the common carp (Cyprinus carpio). Because of its importance as a bird habitat, the area is a Nature Reserve since 1990, a Special Area of Conservation according to Directive 92/43/EEC since 2005 and a part of an Important Bird Area Českobudějovické rybníky according to EU Directive 2009/147/ES since 2009. The studied Bažina fishpond (6.13 ha) is of special conservation value for waterfowl because it is one of the only three nesting sites of the Red-necked Grebe (Podiceps grisegena) in the Czech Republic (Albrecht et al. 2003). 
Bažina fishpond is a hypertrophic water body in turbid state without the occurrence of submerged macrophytes. During the time of this study, there was a phase of clear water in spring, when the photic zone extended down to the bottom and oxygen content was near $100 \%$ saturation within the whole water column. After the mean temperature of the water column increased above $20^{\circ} \mathrm{C}$ at the end of May, a marked vertical stratification developed (Online resource 1). The photic zone decreased to less than $0.2 \mathrm{~m}$ (Fig. 1). This was commensurate with a strong peak in chlorophyll a content, reaching a seasonal maximum over $500 \mu \mathrm{g} . \mathrm{I}^{-1}$, an extremely high value even among hypertrophic fishponds in the same geographic region (cf. Šimek et al. 2019). The vertical stratification was the most pronounced in periods of sunny weather, when the oxygen content reached more than $200 \%$ air saturation near the surface and the water column became hypoxic down from a 20-cm depth (Online resource 1). The extent of the hypoxic layer corresponded with the layer of a loose sediment. On rainy days, the water column got mixed and, consequently, became hypoxic up to the water surface (Online resource 2). The bottom was constantly anoxic. The $\mathrm{pH}$ values followed a similar pattern as oxygen content. Near the water surface, they fluctuated from 9.0 on sunny days to 7.3 on rainy days, respectively, while they ranged from 7.3 to 6.5 at the bottom. In autumn the oxygen content and pH tended to stabilize at values similar to the spring ones but the water transparency remained low (Fig. 1)

The fishpond was used mainly for rearing carp fry or one-year-old fingerlings. In the years preceding this study (i.e. from 2004 to 2011) and also in 2015 and 2016, it was stocked every spring with a total biomass of up to $50 \mathrm{~kg} \mathrm{ha}^{-1}$, which is about $10 \%$ usual stock in production fishponds. The fish was harvested every year during a draw-down in October or November. The draw-down lasted for about one week. In 2012-2014 the fishpond was not stocked but there were some adult carp individuals (about 2 $\mathrm{kg}$ ), which escaped from an upstream fishpond. Their total weight in spring 2012 was estimated to less than $50 \mathrm{~kg} \cdot \mathrm{ha}^{-1}$, which corresponds to the fish stocks in other years. These carp individuals were successively harvested in autumns of 2012-2014. No supplementary food was added to the fish. The mean seasonal height of the water column was about $0.5 \mathrm{~m}$ with the summer minimum of $0.4 \mathrm{~m}$.

\subsection{Assessment of littoral vegetation}

A vegetation map was made in order to document the past and current area of the littoral stands. Background information included local topographic map and ortophotographs of the area made in threeyear intervals from 2004. In August 2013 borders of vegetation units were recorded in the field using an Ashtech GPS Magellan mobile mapper 10. Five vegetation units were defined: Phragmites australis dominated stands, sparse (cover $\leq 35 \%$ ) and dense (>35\%) Typha angustifolia stands, sparse (cover $\leq$ $35 \%$ ) and dense (>35\%) T. latifolia stands. After the fishpond was drained in October, remnants of the dead stands were identified on the fishpond bottom and also recorded. The data were further processed using ArcGIS ESRI 10.

In stands of T. angustifolia, the current state of the plant above-ground parts (uprooting of clumps, the intensity of grazing damage and the proportion of living and dead shoots or leaves in the clumps) was documented on photographs throughout the study. In addition, the whole-plant structure was examined in 
summer 2013. The presence of horizontal rhizomes, ensuring vegetative expansion, was examined in a 0.1-m thick surface layer of the sediment in the close vicinity of ten shoots growing in the sparse stands. In addition, three clumps (having $0.5 \mathrm{~m}$ in diameter) that were only loosely connected to the bottom were lifted up for a visual examination of the state of the rhizomes and roots.

\subsection{Survey of water and sediment characteristics}

Abiotic conditions were investigated in detail in biotopes formerly or currently overgrown with Typha angustifolia: (1) a dense (compact) stand, (2) a sparse stand, and (3) open water in the area where $T$. angustifolia was formerly present but retreated before the start of the investigation (dead stand). These biotopes were investigated at the peak of the plant growing season (13 August 2013). In all three biotopes, the vertical profile consisted of three layers: (1) aquatic photic zone consisting of transparent water, (2) dark zone of water filled with fine loose sediment, and (3) solid bottom sediment. In order to keep the vertical stratification intact, all in situ measurements and sampling were performed from a boat.

Prior the sampling, the depths of the photic and dark zones were measured, respectively. Water conductivity and $\mathrm{pH}$ were estimated in the middle of the photic zone using a portable meter WTW Multi 3430 set $\mathrm{D}$. Mixed water samples were taken from the photic zone using a $0.4 \mathrm{~m}$ long plexiglass tube of $0.05 \mathrm{~m}$ in diameter. Loose sediment was sampled within the dark zone in the same manner. The volume of these samples was approximately $1 \mathrm{I}$. The solid bottom sediment was then sampled with a PVC tube of $0.1 \mathrm{~m}$ in diameter. The samples were stored in a fridge overnight and analysed as described below. All in-situ measurements and samples were taken in triplicate.

Total alkalinity of water was estimated by sample titration with hydrochloric acid to $\mathrm{pH} 4.5$. The content of chlorophyll a was estimated immediately after sampling with the fluorometer Aquafluor 8000-001 (Turner Designs, Canada) using a standard procedure.. The concentrations of the main nutrients were estimated in samples of fishpond water and pore water of the loose sediment. The pore water was obtained by centrifugation of the loose sediment followed by filtration of the supernatant. Total nitrogen concentration was determined using the modified Kjeldahl method (ISO 11261) by mineralization to ammonium ion. Total phosphorus concentration was estimated according to Kopáček and Hejzlar (1995) as phosphate ion after mineralization in perchloric acid. Ammonium and phosphate ions were estimated calorimetrically in the flow-through Flow Injection Analyzer Lachat QC 8500 (Lachat Instruments, USA) using standard protocols. The concentrations of cations $(\mathrm{Ca}, \mathrm{Mg}, \mathrm{K})$ were determined by ion chromatography using 881 Compact IC Pro - Cation (Metrohm AG, Switzerland).

Air-dried samples of the fine loose sediment and the bottom sediment, respectively, were used for analysis of main mineral nutrients. The concentrations of cations ( $\mathrm{Ca}, \mathrm{Mg}$, and $\mathrm{K}$ ) were determined from the soil solution obtained by the Mehlich II extraction method (Zbíral 1995; Zbíral and Němec 2002) using atomic absorption spectroscopy (spectrometer contrAA, Analytik Jena AG, DE). Total phosphorus and nitrogen were estimated after mineralization of ground samples using the same method as in the case of water samples. The content of organic matter in the sediments was estimated from the loss on ignition at 
$550^{\circ} \mathrm{C}$ in a muffle furnace for 4 hours. The results were expressed per unit dry mass obtained by drying partial samples of sediment at $105^{\circ} \mathrm{C}$.

A preliminary survey of redox potential was based on the colour change from reddish to dark grey associated with the reduction of ferric to ferrous iron ( $\mathrm{Fe}^{\mathrm{III}} \rightarrow \mathrm{Fe}^{\mathrm{Il}}$ ) (Mitsch and Gosselink 2015). Iron sticks with an oxidized reddish layer on their surface were placed on the same locations where water and sediments were sampled for chemical analyses. Altogether 18 sticks of $0.5 \mathrm{~m}$ in length were inserted at a $10 \mathrm{~cm}$ depth of the compact bottom sediment, their intermediate parts extended through the layer of the fine loose sediment and their uppermost parts were immersed in water. The sticks were installed in August and checked in November 2013. The redox potential (Eh) was also measured as electric potential between the Pt electrode installed at the surface of the solid sediment and the $\mathrm{Ag} / \mathrm{AgCl}$. $\mathrm{KCl}(3 \mathrm{M})$ electrode immersed in water. The reference electrode had a potential $210 \mathrm{mV}$ against the standard hydrogen electrode (Friis et al. 1998). The measurements took place on the same locations where water and sediments were sampled.

\subsection{Mesocosm experiment}

A mesocosm experiment was set up in order to find out whether the anaerobic fishpond sediment affects the growth of roots of Typha angustifolia and/or causes injury to them. The experiment had two treatments which differed in the type of the rooting substrate: (1) anaerobic sediment taken from the bottom of Bažina fishpond, and (2) washed river sand. The latter was used as a control treatment representing a substrate with negligible microbial activity. The sand was enriched with a slow-dissolving fertilizer Osmocote in order to compensate for the lack of mineral nutrients necessary for the plant growth. The experimental design was 6 planted containers $\cdot 2$ substrate types $\cdot 2$ tubs serving as replicates.

The plants were propagated from seeds collected at Bažina fishpond. Twenty-four plants of similar size were selected out of about 100 plants and planted in 32-liter basket-type containers filled either with the fishpond sediment or the river sand supplemented with $6 \mathrm{~g}$ Osmocote per litre substrate. This dose contained $900 \mathrm{mg}$ total $\mathrm{N}, 600 \mathrm{mg}$ total P, $720 \mathrm{mg} \mathrm{K}$ and $1200 \mathrm{mg} \mathrm{Mg}$. In comparison, the fishpond sediment contained $1584 \mathrm{mg}$ total N, $238 \mathrm{mg}$ total P, $67 \mathrm{mg} \mathrm{K}$, and $139 \mathrm{mg} \mathrm{Mg}$ (all values per 1 litre substrate). Baskets with the same type of substrate were randomly distributed between two fibre-glass tubs. An iron stick was inserted in each basket as an indication of the redox potential (see also Chap. 3.3).

The space between the baskets was filled with the particular rooting substrate and water was added to the tub so as to keep water level about $0.1 \mathrm{~m}$ above the substrate surface. Algal growth was prevented by a $0.05 \mathrm{~m}$ thick layer of perlite on the water surface. The tubs were left in the open air from 30 July to 20 October 2014. At the end of the experiment, the plants were harvested and the following characteristics were determined: number of shoots, number and length of live and dead leaves, respectively, and also the biomass of shoots, rhizomes, and roots after drying the materials at $85^{\circ} \mathrm{C}$ to constant weight.

\subsection{Enclosure experiment}


An enclosure experiment was set up in the fishpond littoral in order to assess the effect of mechanical damage by waterfowl and fish. Two sites were selected in the littoral belt (in the south-eastern and northern parts of the fishpond, respectively). In each site, two pairs of belt transects were laid: one in a sparse (disintegrating) stand and one in a nearby dense stand of. T. angustifolia, respectively. One transect in each pair was fenced while the other was left open. In addition, two islets of $T$. angustifolia (of about $10 \mathrm{~m}^{2}$ each) outside the littoral belt were selected and one of them was fenced.

The transects were $1.2 \mathrm{~m}$ wide and 13-22 $\mathrm{m}$ long depending on the width of the littoral. The fence was made of $1 \mathrm{~m}$ wide, green LLDPE-coated diamond-mesh netting with a $0.02 \mathrm{~m}$ mesh size, which was attached to wooden poles hammered to a depth of $0.5 \mathrm{~m}$ of the compact sediment. It extended from the bottom to a height of $0.5-0.6 \mathrm{~m}$ above the water level.

The experiment lasted from 1 March (i.e., before the start of the growing season) to 31 July 2015 (after the aboveground biomass achieved its seasonal maximum). At the end of the experiment, green shoots were counted in successive 1-m long segments of all transects.

\subsection{Density and activity of geese}

The counts of the Greylag Geese were obtained from the Nature Conservation Agency of the Czech Republic for years 2002-2016. The bird censuses were made from the ground using a standard approach every month. For the purpose of this study, the data were separated according to the main parts (seasons) of the geese annual cycle, i.e. spring migration (February-March), breeding (April-July), and autumnal migration (August-November). Monthly mean counts (within a particular season) and seasonal maximum counts, respectively, were tested for correlation with year.

In addition, the water-bird activity was monitored using an infrared camera trap SG-007 (ScoutGuard, USA) installed in the sparse stand of T. angustifolia from August to November 2013, using a regime of 9 slides in $30 \mathrm{~s}$ following the activation of the motion sensor.

\subsection{Statistical analyses}

The potential differences among biotopes in the chemical characteristics of water and sediments were explored using the one-way ANOVA. The effect of different rooting substrates on the growth characteristics of $T$. angustifolia in the mesocosm experiment was tested using hierarchical ANOVA, where the factor "substrate" was set superior to the "tub" factor. The results of the enclosure experiment were evaluated by testing differences in shoot numbers between the enclosures and the respective control transects using Chi-square test. All the statistical analyses were performed with the Statistica 12 (Statsoft, Inc., USA).

\section{Results}

\subsection{Extent and condition of the littoral vegetation}


The main dominants of littoral stands were Typha angustifolia (growing in depths of $0.3-0.4 \mathrm{~m}$ in summer), T. latifolia (in depths 0.1-0.2 $\mathrm{m}$ ) and Phragmites australis (forming a narrow belt along the dams and the embankment) (Fig. 2). The area of helophyte stands available for bird nesting was 28721 $\mathrm{m}^{2}$ and $9457 \mathrm{~m}^{2}$ in 2004 and 2013, respectively, which corresponds to 48 and $16 \%$ of the total area of the fishpond. These data indicate that the area of helophyte stands decreased by $2 / 3$ in ten years. The decline was the most pronounced in the south-eastern part of fishpond, where dense stands of $T$. angustifolia originally covered much of the area.

The marked reduction in area was accompanied with the apparent disintegration of the current stands of T. angustifolia. The shoot densities frequently decreased toward the waterward edge of the stands. At some sites, the whole stands were sparse, formed by isolated islets occurring several meters apart. The smallest islets consisted of individual clumps having about 10-20 shoots, of which several were flowering. Shoots occurring at the clump perimeter were often damaged by grazing (Online resource 3a). We did not find any horizontal rhizomes growing from the examined clumps within a 10-cm upper layer of the solid sediment or apical rhizome buds protruding through the bottom near the clumps. Some clumps were uprooted (Online resource $3 \mathrm{~b}$ ). They occurred along the water edge of the littoral belt and throughout the stands in the south-eastern part of the fishpond. Although the clumps had green shoots, their belowground systems were severely damaged (Online resource $3 \mathrm{c}$ ). In the south-eastern part of the fishpond, the belowground systems of the isolated clumps formed compact blocks about $0.5 \mathrm{~m}$ in diameter and 0.6 to $0.8 \mathrm{~m}$ in height. They had very weak or no connection with the bottom. Much of their surface was exposed to water and the loose sediment. No living rhizomes extended from them and roots protruding their surface were short and thick and often had necrotic tips. The blocks smelled of organic acids.

\subsection{Physico-chemical conditions in the littoral biotopes}

We found no significant differences in water quality among the three littoral biotopes (dense, sparse and dead littoral stands of $T$. angustifolia, respectively) (Table 1). The values were consistent with the seasonal course reported in the Site description (Chap. 3.1): the water transparency was only $7 \mathrm{~cm}$, the concentrations of chlorophyll a reached more than $500 \mu \mathrm{g} . \mathrm{I}^{-1}$ and $\mathrm{pH}$ ranged from 8.5 to 9.3 
Table 1

Nutrient contents in the water column, in the pore water of the loose sediments, and in the dry matter of the loose and the solid sediments in August 2013, respectively. TN - total nitrogen, TP - total

phosphorus, LOI - organic matter content estimated as loss on ignition. Mean \pm standard error, $\mathrm{n}=2$ for the water column and $n=3$ for the other materials. Significant differences among the littoral biotopes (ANOVA followed by post-hoc comparisons using Tukey test) are given in bold and indicated by different small letters.

\begin{tabular}{|c|c|c|c|c|c|c|c|c|c|c|c|c|}
\hline \multicolumn{13}{|c|}{ Water in photic zone } \\
\hline Parameter & dense & & & & sparse & & & & dead & & & \\
\hline $\mathrm{TN}\left(\mathrm{mg} . \mathrm{I}^{-1}\right)$ & 2.29 & \pm & 0.08 & & 2.29 & \pm & 0.03 & & 2.18 & \pm & 0.04 & \\
\hline $\mathrm{TP}\left(\mu \mathrm{g} . \mathrm{I}^{-1}\right)$ & 278 & \pm & 15 & & 293 & \pm & 11 & & 323 & \pm & 4 & \\
\hline $\mathrm{K}\left(\mathrm{mg} . \mathrm{I}^{-1}\right)$ & 7.4 & \pm & 0.3 & & 7.5 & \pm & 0.1 & & 7.4 & \pm & 0.1 & \\
\hline $\mathrm{Ca}\left(\mathrm{mg} . \mathrm{I}^{-1}\right)$ & 33.7 & \pm & 1.4 & & 35.2 & \pm & 0.3 & & 34.9 & \pm & 0.8 & \\
\hline \multirow[t]{2}{*}{$\operatorname{Mg}\left(\mathrm{mg} . \mathrm{I}^{-1}\right)$} & 6.3 & \pm & 0.3 & & 6.6 & \pm & 0.1 & & 6.5 & \pm & 0.2 & \\
\hline & \multicolumn{12}{|c|}{ Pore water in loose sediment } \\
\hline $\mathrm{TN}\left(\mathrm{mg} . \mathrm{l}^{-1}\right)$ & 5.38 & \pm & 0.50 & $\mathbf{a}$ & 9.25 & \pm & 1.46 & b & 3.41 & \pm & 0.21 & a \\
\hline $\mathrm{TP}\left(\mu \mathrm{g} . I^{-1}\right)$ & 274 & \pm & 98 & a & 900 & \pm & 275 & b & 143 & \pm & 29 & a \\
\hline $\mathrm{K}\left(\mathrm{mg} . \mathrm{I}^{-1}\right)$ & 7.6 & \pm & 0.1 & & 9.4 & \pm & 0.8 & & 7.7 & \pm & 0.4 & \\
\hline $\mathrm{Ca}\left(\mathrm{mg} . \mathrm{l}^{-1}\right)$ & 35.5 & \pm & 2.0 & & 42.3 & \pm & 2.5 & & 37.8 & \pm & 1.4 & \\
\hline $\operatorname{Mg}\left(\mathrm{mg} . \mathrm{I}^{-1}\right)$ & 7.0 & \pm & 0.4 & & 8.5 & \pm & 0.5 & & 7.1 & \pm & 0.4 & \\
\hline \multirow[t]{2}{*}{$\mathrm{Fe}\left(\mathrm{mg} . \mathrm{I}^{-1}\right)$} & 0.44 & \pm & 0.06 & $a$ & 0.19 & \pm & 0.01 & b & 0.26 & \pm & 0.04 & $\mathbf{b}$ \\
\hline & \multicolumn{12}{|c|}{ Dry matter of loose sediment } \\
\hline Parameter & dense & & & & sparse & & & & dead & & & \\
\hline $\mathrm{TN}\left(\mathrm{mg} \cdot \mathrm{kg}^{-1}\right)$ & 13691 & \pm & 2800 & & 18400 & \pm & 1713 & & 17851 & \pm & 953 & \\
\hline $\mathrm{TP}\left(\mathrm{mg} \cdot \mathrm{kg}^{-1}\right)$ & 858 & \pm & 67 & a & 1381 & \pm & 152 & b & 1228 & \pm & 114 & $a b$ \\
\hline $\mathrm{K}\left(\mathrm{mg} \cdot \mathrm{kg}^{-1}\right)$ & 351 & \pm & 47 & & 420 & \pm & 36 & & 456 & \pm & 70 & \\
\hline $\mathrm{Ca}\left(\mathrm{mg} \cdot \mathrm{kg}^{-1}\right)$ & 4559 & \pm & 594 & a & 6902 & \pm & 707 & $a b$ & 7503 & \pm & 301 & b \\
\hline $\operatorname{Mg}\left(\mathrm{mg} \cdot \mathrm{kg}^{-1}\right)$ & 509 & \pm & 95 & & 746 & \pm & 82 & & 904 & \pm & 113 & \\
\hline LOI (\%) & 40.4 & \pm & 2.8 & $a b$ & 30.3 & \pm & 2.1 & $a$ & 48.5 & \pm & 3.6 & b \\
\hline
\end{tabular}




\begin{tabular}{|llllllllllll|}
\hline \multicolumn{8}{|c|}{ Water in photic zone } \\
\hline $\mathrm{TN}\left(\mathrm{mg} \cdot \mathrm{kg}^{-1}\right)$ & 1705 & \pm & 3 & 3055 & \pm & 1228 & 2470 & \pm & 762 \\
$\mathrm{TP}\left(\mathrm{mg} \cdot \mathrm{kg}^{-1}\right)$ & 257 & \pm & 20 & 412 & \pm & 167 & 187 & \pm & 12 \\
\hline $\mathrm{K}\left(\mathrm{mg} \cdot \mathrm{kg}^{-1}\right)$ & 96 & \pm & 6 & 175 & \pm & 61 & 87 & \pm & 23 \\
$\mathrm{Ca}\left(\mathrm{mg} \cdot \mathrm{kg}^{-1}\right)$ & 1609 & \pm & 202 & 3025 & \pm & 1494 & 3212 & \pm & 918 \\
$\mathrm{Mg}\left(\mathrm{mg} \cdot \mathrm{kg}^{-1}\right)$ & 217 & \pm & 13 & 330 & \pm & 95 & 259 & \pm & 56 \\
\hline $\mathrm{LOI}(\%)$ & 12.2 & \pm & 2.0 & 17.7 & \pm & 6.0 & 6.0 & \pm & 1.3 \\
\hline
\end{tabular}

A layer of loose sediment, formed by organomineral particles suspended in water, was found between the layer of water and the bottom (solid) sediment in all littoral biotopes. Its thickness was $0.30-0.40 \mathrm{~m}$ both in the dense and sparse stands, respectively (Table 2). It filled the space between the clumps, thus surrounding the plant root and rhizome systems. The pore water of the loose sediment had higher contents of both total nitrogen and total phosphorus in the sparse stand as compared with the dense and dead stands (Table 1). Additionally, loose sediment in dense stands had significantly lower dry matter content of total phosphorus and $\mathrm{Ca}$ as compared with the sparse and dead stands, content of other nutrients (total nitrogen, $\mathrm{K}, \mathrm{Mg}$ ) were also lower in dense stands even if the differences were not significant (Table 1). On the other hand, we found no significant differences among the biotopes in the nutrient contents in the dry matter of the solid sediment.

Table 2

Sediment characteristics of $T$. angustifolia biotopes. The redox potential was measured at the interface between the loose and the solid sediments, respectively. The numbers denote medians (minimum; maximum).

\begin{tabular}{|lll|}
\hline Biotope & $\begin{array}{l}\text { Depth of loose sediment } \\
(\mathbf{c m})\end{array}$ & $\begin{array}{l}\text { Redox potential } \\
(\mathbf{m V})\end{array}$ \\
\hline Dense stand & $35(34 ; 38)$ & $30(-87 ; 332)$ \\
\hline Sparce stand & $36(30 ; 37)$ & $-13(-140 ; 10)$ \\
\hline Dead stand & $21(14 ; 26)$ & $-155(-195 ;-52)$ \\
\hline
\end{tabular}

The numeric values of redox potential, measured in the solid sediment, varied within each biotopes and mostly overlapped among them. Most values ranged from - 100 to $+100 \mathrm{mV}$ (Table 2). The long-term assessment of redox potential using the iron sticks revealed reducing conditions in the sediments in all littoral biotopes. The colour of the iron sticks was dark grey on their parts inserted both in the solid and the loose sediments and reddish on parts immersed in water (Online resource 3e). We also observed ebullition of gas bubbles from the fishpond bottom inside the sparse and the dead stands, respectively. 


\subsection{Mesocosm experiment}

The fishpond sediment differed from sand in redox conditions as indicated by the colour of the iron sticks, which was reddish in the sand and dark grey in the sediment, respectively.

The type of substrate (fishpond sediment or sand enriched with mineral nutrients) had pronounced effects on the plant growth characteristics. The aboveground parts of the plants grew generally better in the fishpond sediment. The plants had a significantly greater length of newly produced live leaves, and significantly greater shoot biomass at the end of the experiment as compared with the plants cultivated in sand. On the other hand, no significant effects were found on either root or rhizome biomass (Table 3) or the ratio of rhizome: shoot biomass. Nevertheless, the ratios of belowground/shoot biomass and root/shoot biomass were significantly smaller in the fishpond sediment, indicating a shift in biomass allocation from roots to shoots. No dead root tips or other symptoms of root injury were observed in either substrate.

Table 3

Growth characteristics of $T$. angustifolia plants grown in either sandy substrate or fishpond sediment in a common garden experiment. DW - biomass dry weight. Belowground biomass comprises the biomass of rhizomes and roots. Means \pm standard deviations, $n=12$. Statistically significant differences are given in bold.

\begin{tabular}{|lllllll|}
\hline Growth characteristic & \multicolumn{2}{l}{ Cultivation substrate } & F & p \\
\hline & Sand & \multicolumn{7}{l|}{ Sediment } \\
\hline Total length of produced leaves (cm) & $1374 \pm$ & 551 & $2297 \pm$ & 613 & 19.63 & $<0.001$ \\
\hline Final shoot DW (g) & $34.82 \pm$ & 7.40 & $52.62 \pm$ & 15.08 & 20.68 & $<0.001$ \\
\hline Final rhizome DW (g) & $43.82 \pm$ & 14.91 & $49.82 \pm$ & 17.50 & 0.79 & 0.384 \\
\hline Final root DW (g) & $15.09 \pm$ & 3.57 & $13.55 \pm$ & 3.76 & 0.97 & 0.336 \\
\hline Belowground / shoot DW & $1.74 \pm$ & 0.50 & $1.29 \pm$ & 0.59 & 4.75 & $\mathbf{0 . 0 4 1}$ \\
\hline Rhizome / shoot DW & $3.58 \pm$ & 1.31 & $3.13 \pm$ & 1.14 & 2.70 & 0.115 \\
\hline Root / shoot DW & $0.39 \pm$ & 0.13 & $0.31 \pm$ & 0.10 & $\mathbf{2 9 . 9 2}$ & $<\mathbf{0 . 0 0 1}$ \\
\hline
\end{tabular}

\subsection{Enclosure experiment}

In the enclosure experiment in situ, fencing had a marked protecting effect on shoot density. The shoot densities were significantly higher in fenced transects than in the unfenced ones $\left(\chi^{2}=63.2, \mathrm{df}=1, p<\right.$ $0.001)$. When looking into detail, it was due to differences in shoot densities in the sparse stands $\left(\chi^{2}=\right.$ $109, d f=1, p<0.001)$. On the other hand, fencing had no significant effect on the dense stands $\left(\chi^{2}=0.6\right.$, $d f=1, p=0.451$ ), where the shoot densities were similar in fenced and unfenced transects (Fig. 3).

\subsection{Geese and fish activity}


In 2013 frequent clipping damage occurred especially in the sparse stands of $T$. angustifolia. As documented by photographs captured with a camera trap, they were caused by geese (Online resource $3 d)$.

Apart from one exception, the geese were observed on the fishpond only during the time of breeding. Their numbers increased considerably over the years of the study. While the seasonal maximum counts were 2-12 in 2002-2010, they achieved as much as 44 in 2012, which corresponds to more than seven individuals per hectare. The correlations between the geese numbers and year were highly significant. This held both for the monthly means and maximum seasonal counts, within the breeding season (Fig. 4).

In addition to geese grazing on shoots, adult carp individuals (about $2 \mathrm{~kg}$ ) were repeatedly observed to shake small isolated clumps (up to $0.25 \mathrm{~m}^{2}$ ) in the sparse stand of $T$. angustifolia in 2012-2014.

\section{Discussion}

\subsection{Effects of abiotic factors}

All the physico-chemical characteristics of water quality confirmed the extremely high trophic status of the fishpond (cf. Pechar 2000, Šimek et al. 2019). The same was true for both the pore water and dry matter of the loose sediment (cf. Čížková et al. 2001).

The hypoxic layer of the loose sediment, which was formed in late spring as the temperature increased above $20^{\circ} \mathrm{C}$ (Online resource 1), was not reported in previous research. Although some oxygen was found there, it could be due to a temporary $\mathrm{O}_{2}$ supply from the photosynthetic production in the overlying photic layer during daylight. Lower $\mathrm{O}_{2}$ contents could thus be expected in the loose sediment at night. This assumption is supported by the presence of the reduced iron forms on the iron sticks (Online resource $3 e$, ), indicating that iron reduction generally prevailed over its oxidation. The low redox potentials, found in the solid bottom sediment, occur also in other similar hypertrophic or eutrophic fishponds in the region (Čížková et al. 2001).

Among the environmental components investigated (i.e. fishpond water, pore water and dry matter of the loose sediment and dry matter of the solid sediment, respectively), some differences among the biotopes were revealed in the pore water and dry matter of the loose sediments, respectively. The higher contents of total nitrogen and total phosphorus, found in the sparse as compared with the dense stand (Table 1), may indicate its higher trophic status. Nevertheless, as the nutrient values were extremely high in all the biotopes, it is questionable whether the differences among them might have a discernable effect on the plants. In addition, it is unlikely that high nutrient levels would have a deleterious effect per se. As has been documented for Phragmites australis, the decline of its stands on eutrophic sites is not due to the nutrient levels but rather to the secondary effect of eutrophication, i.e. toxic substances originating by the anaerobic decomposition of the organic matter present (van der Putten 1997, Armstrong et al. 1996, 
Čížková et al. 1999, Armstrong and Armstrong 2001). It seems reasonable to assume that the same mechanism would hold also for T. angustifolia.

Reducing conditions, such as found both in the loose and the solid sediments, promote the formation of substances toxic to plants (e.g. Reddy and De Laune 2008, Lamers et al. 2012). Among them, reduced forms of iron might be considered in this study because they were constantly present in the fishpond sediment, as indicated by the reduced state of the Fe redox pair on the surface of the iron sticks and redox potential below $+100 \mathrm{mV}$. Toxic effects or the reduced forms of iron were demonstrated in other wild wetland plants (Lucassen et al. 2000; Li et al. 2017) and are well known in rice (Becker and Asch 2005). On the other hand, very low Fe contents (below $1 \mathrm{mg} . \mathrm{I}^{-1}$ ) were found in the pore water of the loose sediment in all three biotopes, which makes its toxic effect highly improbable.

Although the fishpond sediment was reduced and therefore potentially toxic, no negative effect of it on the plants was revealed by the mesocosm cultivation experiment (Table 3). On the contrary, the plants prospered even better in the fishpond sediment than in the control substrate (sand enriched with the mineral nutrients). This might have been caused by a more balanced nutrient supply in the organic fishpond sediment, which could not be fully simulated by adding the inorganic fertilizer to the sand.

These results suggest that $T$. angustifolia is well adapted to anaerobic conditions. This corresponds with the finding by Čížková et al. (1996) that it can grow on a strongly reducing black mud in the fishpond littoral. This is probably due to the morphology of the plant having extraordinarily high contents of gas spaces both in shoots and roots (Seago et al.2005; Schweingruber et al. 2020).

\subsection{Effects of biotic factors}

Generally, either fish (Hroudová et al. 2010; Francová et al. 2019a) and/or water birds (Chaichana et al. 2011; Bakker et al. 2018) can destroy the littoral stands when they occur in high densities.

The enclosure experiment (Fig. 3) proved a strong destructive effect of animals on the littoral stands but its design did not allow to separate the effects of fish and water birds. The effect of fish can, however, be excluded because only fry was stocked in the fishpond in the particular year (2015). The T. angustifolia clumps could not be damaged by fry because it is small-sized $(10-20 \mathrm{~g}, 6-10 \mathrm{~cm})$ and feeds on small zooplankton. It can therefore be concluded that littoral destruction by geese was the sole cause of the stand decline in 2015 and probably also in the other years when fry was stocked in the fishpond. Increasing pressure on the littoral stands by geese can be derived from the geese counts during the breeding period, which increased more than four times during the time of the study (Fig. 4). Moreover, night records with the camera trap (Online resource 3d) show that geese grazed on $T$. angustifolia plants also during late summer and autumn, when they gathered prior migration. At that time, their presence was not detected by the censuses because they fed on surrounding fields during daytime and occurred on the fishpond only at night.

In addition to geese, some damage could have been caused by the adult individuals of carp present in the fishpond in 2012-2014. Because of lack of large zooplankton in summer, carp feeds on zoobenthos, 
which occurs on root surfaces in greater densities than in the surrounding anaerobic mud owing to oxygen leaking from the roots (Hargeby et al. 1994; Ságová-Marečková and Květ 2002). While moving around the isolated clumps the carp probably broke buds extending from the rhizomes (Online resource 3c) and thus prevented vegetative spreading. Compared with the solid mineral bottom, the loose organic sediment may facilitate the searching for food by fish on root surfaces inside the already damaged plant stands. In addition, Boarman and Fuller (1981) and Weisner (1991) proposed that littoral plants may be anchored less well in soft sediments than in solid ones, which makes them more vulnerable to disturbance. Insufficient anchorage of the plants would ultimately lead to uprooting such observed in this study (Online resource $3 b$ ).

It is interesting to note that fencing had a protecting effect only on sparse stands but not on the dense ones (cf. Figure 3). This is probably due to the fact that geese easily penetrated inside the sparse stands through gaps between the clumps. On the other hand, they damaged the dense stands only on their waterward side. This was observed repeatedly but could not be detected by the experimental design used.

\subsection{Possible management measures}

Overstocking with cyprinid fish has commonly been considered a limit for fishponds supporting populations of water-birds (Broyer and Calenge 2010, Broyer and Curtet 2012). This study draws attention to an additional conservation dilemma, i.e. how to preserve littoral stands in the presence of increasing densities of Greylag Geese (Fig. 4). Herbivorous birds such as geese do not compete with fish for food because they feed on surrounding crop fields and grasslands. They also take profit from legal protection in nature reserves. As the geese numbers increase, they deprive the rare water-bird species of their nesting opportunities. This phenomenon may grow in importance in the near future owing changed migratory behaviour in response to the ongoing climate change (Podhrázský et al. 2017).

As Bakker et al. (2018) point out, the conservation of both the littoral stands and high geese numbers seems infeasible. There are two possible solutions for this dilemma: (1) negative effects of geese can be limited by the restriction of their populations, (2) or it can be compensated by supporting the recovery of the littoral stands. If a fishpond is to serve as a breeding site for a variety of water bird species, then a control of the geese population by hunting might be needed. Lethal scaring has been reported as a successful measure to prevent geese damage in agricultural crops (Månsson 2017). It may be worth considering to prevent a destruction of littoral stands in late summer, after the protected bird species have raised their young and the geese gather in nature reserves in order to escape from hunting. Nevertheless, this may be hard to achieve in a nature reserve because of conflicts of interests with local stakeholders such as local inhabitants and tourists. Scaring of geese with laser has also been studied, but so far with limited results (Clausen et al. 2019).

An alternative to geese scaring may be to support the regeneration of the stands by a regular partial water draw-down, which would expose the littoral zone once in several years. Summer drainage promotes both the vegetative and generative reproduction of the plants (Rea 1996, Hroudová et al. 2010). It also prevents geese from breeding on the young plants provided the water table is kept low till autumn, when 
the shoots are tall enough. At the same time, a neighboring fishpond should be filled with water so as to provide a habitat for the protected water bird species.

\section{Conclusion}

In the hypertrophic fishpond serving as a nature reserve for rare water-bird species, the area suitable for nesting decreased by $2 / 3$ over a decade. Although chemical analyses of water and sediments confirmed hypertrophic conditions of the ecosystem, a follow-up mesocosm experiment did not prove any negative effect of the sediment quality on the plants. In contrast, a field enclosure experiment show a significant biotic influence, which was attributed to shoot grazing by large numbers of geese. A damage of the plant belowground parts, found in isolated clumps of heavily disintegrated stands, was ascribed to large carp individuals, albeit in small numbers. The study points to a conservation dilemma caused by large numbers of geese destroying littoral stands in a fishpond nature reserve, which then looses its nesting function for other water-bird species.

\section{Declarations}

\section{Acknowledgements}

We are grateful to P. Oberreiter (head of the fisheries management of the Forests and Fishponds of the city of České Budějovice, Ltd.), T. Bodnár and J. Pykal (Nature Conservation Agency of the Czech Republic), P. Stehlík (Regional Office of South Bohemia) and J. Staněk (Fishponds and Forests of the City of České Budějovice, Ltd.) for valuable feedback. We thank our colleagues P. Musil, I. Šetlíková and L. Šimek for helpful discussions, P. Rost for advice on statistical analyses and S. Svidenská for translation of the manuscript.

\section{Declarations}

\section{Funding}

This article was financially supported by project No. 081/2016/Z of the Grant Agency of the University of South Bohemia, by a long-term research development project no. RVO 67985939 of the Academy of Sciences of the Czech Republic and by contract No. KUJCK 43725/2014 OZZL of the Regional Office of South Bohemia.

\section{Conflicts of interest}

The authors declare that there is no conflict of interests regarding the publication of this article. 


\section{Ethics Approval}

The field study was conducted in accordance with local legislation, namely Acts No. 17/1992 and No. 114/1992 of the Czech Republic and Council Directive 2009/147/EC. The use of local soil and plant materials in the cultivation experiment as well as the performance of the field experiment were permitted by contract No. KUJCK 43725/2014 OZZL of the Regional Office of South Bohemia.

\section{Consent to participate}

Not applicable.

\section{Consent for publication}

The Forests and Fishponds of the city of České Budějovice, Ltd. provided consent with publication of the information on fish stocks and fishpond management. The Nature Conservation Agency of the Czech Republic provided consent with publication of the information on geese counts.

\section{Data availability}

The data on fish stocks were provided on request from the P. Oberreiter, head of the fisheries management of the Forests and Fishponds of the city of České Budějovice, Ltd. The data on geese counts were provided on request from T. Bodnár and J. Pykal of the Nature Conservation Agency of the Czech Republic. The datasets analysed during the study are included in this article.

\section{Code availability}

Not applicable

\section{Authors' contributions}

All authors contributed to the study conception and design. Material preparation, data collection and analysis were performed by RS. The first draft of the manuscript was written by RS and all authors commented on previous versions of the manuscript. All authors read and approved the final manuscript.

\section{References}

Albrecht J, et al (2003) Českobudějovicko. Protected areas of the Czech Republic VIII. AOPK ČR, Praha, EkoCentrum, Brno. [In Czech] 
Armstrong J, Armstrong W (2001) An overview of the effects of phytotoxins on Phragmites australis in relation to die-back. Aquat Bot 69: 251-268.

Armstrong J, Armstrong W, Zenbin W, Afreen-Zobayed F (1996) A role of phytotoxins in the Phragmites die-back syndrome. Folia Geobot. 31: 127-142.

Bakker ES, Veen C, ter Heerdt G, HuigN, Sarneel J (2018) High grazing pressure of geese threatens conservation and restoration of reed belts. Frontiers in Plant Science, 9, 1649.

Baxa M, Šulcová J, Kröpfelová L, Pokorný J, Potužák J (2019) The quality of sediment in shallow water bodies - Long-term screening of sediment in Czech Republic. A new perspective of nutrients and organic matter recycling in agricultural landscapes. Ecol Eng 127: 151-159.

Becker M, Asch F (2005) Iron toxicity in rice - conditions and management concepts. J Plant Nutr Soil Sci 168: $558-573$.

Bíró P (1995) Management of pond ecosystems and trophic webs. Aquaculture 129: 373-386.

Boorman LA, Fuller RM (1981) The changing status of reedswamp in the Norfolk Broads. J Appl Ecol 18: 241-269.

Broyer J, Calenge C (2010) Influence of fish-farming management on duck breeding in French fish pond systems. Hydrobiologia 637: 173-185.

Broyer J, Curtet L (2012) Biodiversity and fish farming intensification in French fishpond systems. Hydrobiologia 694: 205-218.

Chaichana R, Leah R, Moss B (2011) Seasonal impact of waterfowl on communities of macrophytes in a shallow lake. Aquat Bot 95: 39-44.

Čižková H, Brix H, Kopecký J, Lukavská J (1999) Organic acids in the sediments of wetlands dominated by Phragmites australis: evidence of phytotoxic concentrations. Aquat Bot 64: 303-315.

Čížková H, Pechar L, Husák Š, Květ J, Bauer V, Radová J, Edwards K (2001) Chemical characteristics of soils and pore waters of three wetland sites dominated by Phragmites australis: relation to vegetation composition and reed performance. Aquat Bot 69: 235-249.

Čížková H, Strand JA, Lukavská J (1996) Factors associated with reed decline in a eutrophic fishpond, Rožmberk (South Bohemia, Czech Republic). Folia Geobot 31: 73-84.

Clausen KK, Marcussen LK, Knudsen N, Balsby TJ, Madsen J (2019) Effectiveness of lasers to reduce goose grazing on agricultural grassland. Wildlife Biology 1:1-8.

Crivelli AJ (1983). The destruction of aquatic vegetation by carp. Hydrobiologia 106: 37-41. 
Flis A, Gwiazda R (2018) Diet and feeding of nestling Little Bitterns Ixobrychus minutus at fishponds: testing a new method for studying a difficult-to-monitor species. Bird Study 65: 257-260.

Francová K, Šumberová K, Janauer GA, Adámek Z (2019a). Effects of fish farming on macrophytes in temperate carp ponds. Aquac Int 27: 413-436.

Francová K, Šumberová K, Kučerová A, Čtvrtlíková M, Šorf M, Borovec J, Drozd B, Janauer GA, Vrba J (2019b). Macrophyte assemblages in fishponds under different fish farming management. Aquat Bot 159: 103131.

Friis EP, Anderson JET, Madsen LL, Bonander N, Møller P, Ulstrup J (1998) Dynamics of Pseudomonas aeruginosa azurin and its Cys3Ser mutant at single-crystal gold surfaces investigated by cyclic voltammetry and atomic force microscopy, Electrochim Acta 43: 1114-1122.

Gergely Z, Mészáros LA, Szabad J, Székely T (2009) Old nests are cues for suitable breeding sites in the Eurasian penduline tit Remiz pendulinus. J Avian Bio 40: 2-6.

Hargeby A, Andersson G, Blindow I, Johansson S (1994) Trophic web structure in a shallow eutrophic lake during a dominance shift from phytoplankton to submerged macrophytes. Hydrobiologia 279: 83-90.

Hejný S, Hroudová Z, Květ J (2002) Fishpond vegetation: an historical view. In: Květ J, Jeník J, Soukupová $L$ (eds.) Freshwater wetlands and their sustainable future. A case study of Třeboň Basin Biosphere Reserve, Czech Republic. UNESCO, Paris, and CRC Press, Boca Raton, pp 63-95.

Hroudová Z, Kloubec B, Zákravský P (2010) Will the reed stands regenerate in the State Nature Reserve Velký a Malý Tisý? Ochrana prírody 3: 12-15. [in Czech with English sum.]

IUCN (1997) Fishing for a living: the ecology and economics of fishponds in Central Europe. IUCN, Switzerland.

Janda J, Ševčík J (2002) Avifauna of the Třeboň fishponds and new wetlands. In: Květ J, Jeník J, Soukupová $L$ (ed), Freshwater wetlands and their sustainable future. A case study of Třeboň Basin Biosphere Reserve, Czech Republic. UNESCO, Paris, and CRC Press, Boca Raton, pp 475-480

Kestemont P (1995) Different systems of carp production and their impacts on the environment. Aquaculture 129: 347-372.

Kopáček J, Hejzlar J (1995) Semi-micro determination of total phosphorus in soils, sediments, and organic materials: A simplified perchloric acid digestion procedure. Commun Soil Sci Plan 26: 19351946.

Lamers LPM, van Diggelen JMH, Op den Camp HJM, Visser EJW, Lucassen ECHET, Vile MA, Jetten MSM, Smolders AJP, Roelofs JGM (2012) Microbial transformations of nitrogen, sulphur, and iron dictate vegetation composition in wetlands: a review. Front Microbiol 3: 1-12. 
Li WC, Deng H, Wong MH (2017) Effects of Fe plaque and organic acids on metal uptake by wetland plants under drained and waterlogged conditions. Environ Pollut 231: 732-741.

Lucassen ECHET, Smolders AJP, Roelofs JGM (2000) Increased groundwater levels cause iron toxicity in Glyceria fluitans (L.). Aquat Bot 66: 321-327.

Månsson J (2017) Lethal scaring - Behavioral and short-term numerical response of greylag goose Anser anser. Crop Protection 96: 258-264.

Miklín J, Macháček P (2016) Birds of Lednické rybníky Fishponds (Czech Republic). J Maps 12: 239248.

Mitsch WJ, Gosselink JG (2015) Wetlands. 5th edition. Wiley, Hoboken.

Nieoczym M (2010) The importance of fishponds to the preservation of avian biodiversity in agricultural landscape. Teka Kom. Ochr. Kszt. Środ. Przyr. - OL PAN 7: 290-296.

Ostendorp W (1989) 'Die-back' of reeds in Europe - a critical review of literature. Aquat Bot 35: 5-26.

Pechar L (2000) Impacts of long-term changes in fishery management on the trophic level water quality in Czech fish ponds. Fisheries Manag Ecol 7: 23-31.

Podhrázský M, Musil P, Musilová Z, Zouhar J, Adam M, Závora J, Hudec K (2017) Central European Greylag Geese Anser anser show a shortening of migration distance and earlier spring arrival over 60 years. Ibis 159: 352-365.

Polak M (2007) Nest-site selection and nest predation in the Great Bittern Botaurus stellaris population in eastern Poland. Ardea 95: 31-38.

Potužák J, Hůda J, Pechar L (2007) Changes in fish production effectivity in eutrophic fishponds impact of zooplankton structure. Aquacult Int 15: 201-210.

Rea N (1996) Water levels and Phragmites. decline from lack of regeneration or dieback from shoot death. Folia Geobot 31: 85-90.

Reddy KR, De Laune RD (2008) Biogeochemistry of Wetlands. Boca Raton, CRC Press.

Ságová-Marečková M, Květ J (2002) Impact of oxygen released by the roots of aquatic macrophytes on composition and distribution of benthic macroinvertebrates in a mesocosm experiment. Arch Hydrobiol 155: $567-584$.

Schlumberger O, Girard P (2013) Mémento de pisciculture d'étang: 5e édition. Quæ, Versailles.

Schweingruber FH, Kučerová A, Adamec L, Doležal J (2020) Anatomic atlas of aquatic and wetland plant stems. Springer. 
Seago Jr JL, Marsh LC, Stevens KJ, Soukup A, Votrubová O, Enstone DE (2005) A re-examination of the root cortex in wetland flowering plants with respect to aerenchyma. Ann Bot 96: 565-579.

Šimek K, Grujčić V, Nedoma J, Jezberová J, Šorf M, Matoušů A, Pechar L, Posch T, Bruni EP, Vrba J (2019) Microbial food webs in hypertrophic fishponds: Omnivorous ciliate taxa are major protistan bacterivores. Limnol Oceanogr 64: 2295-2309.

Švažas S, Stanevičius V (1998) Waterfowl of the large fish pond systems in Lithuania. Acta Zool Lit 8: 69-84.

van der Putten WH (1997) Die-back of Phragmites australis in European wetlands: an overview of the European research programme on reed die-back and progression (1993-1994). Aquat Bot 59: 263-275.

Weber MJ, Brown ML (2009) Effects of common carp on aquatic ecosystems 80 years after „carp as a dominant”: ecological insights for fisheries management. Rev Fish Sci Aquac 17: 524-537.

Weisner SEB (1991) Within-lake patterns in depth penetration of emergent vegetation. Freshwater Biol $26: 133-142$.

Zbíral J (1995) Soil analysis I. Unified working procedures. SKZÚZ Brno. [In Czech]

Zbíral J, Němec P (2002) Comparison of Mehlich 2, Mehlich 3, CAL, Egner, Olsen, and $0.01 \mathrm{M} \mathrm{CaCl2}$ extractants for determination of phosphorus in soils. Commun Soil Sci Plant Anal 33: 3405-3417.

\section{Tables}

Table 1. Nutrient contents in the water column, in the pore water of the loose sediments, and in the dry matter of the loose and the solid sediments in August 2013, respectively. TN total nitrogen, TP - total phosphorus, LOI - organic matter content estimated as loss on ignition. Mean \pm standard error, $n=2$ for the water column and $n=3$ for the other materials. Significant differences among the littoral biotopes (ANOVA followed by post-hoc comparisons using Tukey test) are given in bold and indicated by different small letters. 


\begin{tabular}{|c|c|c|c|c|c|c|c|c|c|c|}
\hline & \multicolumn{10}{|c|}{ Water in photic zone } \\
\hline Parameter & \multicolumn{2}{|c|}{ dense } & & \multicolumn{2}{|c|}{ sparse } & \multicolumn{5}{|c|}{ dead } \\
\hline $\mathrm{TN}\left(\mathrm{mg} . \mathrm{l}^{-1}\right)$ & $2.29 \pm$ & 0.08 & & $2.29 \pm$ & 0.03 & & 2.18 & \pm & 0.04 & \\
\hline $\mathrm{TP}\left(\mu \mathrm{g} . \mathrm{l}^{-1}\right)$ & $278 \pm$ & 15 & & $293 \pm$ & 11 & & 323 & \pm & 4 & \\
\hline $\mathrm{K}\left(\mathrm{mg} \cdot \mathrm{l}^{-1}\right)$ & $7.4 \pm$ & 0.3 & & $7.5 \pm$ & 0.1 & & 7.4 & \pm & 0.1 & \\
\hline $\mathrm{Ca}\left(\mathrm{mg} \cdot \mathrm{l}^{-1}\right)$ & $33.7 \pm$ & 1.4 & & $35.2 \pm$ & 0.3 & & 34.9 & \pm & 0.8 & \\
\hline $\operatorname{Mg}\left(\mathrm{mg}^{-1} \mathrm{l}^{-1}\right)$ & $6.3 \pm$ & 0.3 & & $6.6 \pm$ & 0.1 & & 6.5 & \pm & 0.2 & \\
\hline \multicolumn{11}{|c|}{ Pore water in loose sediment } \\
\hline$\overline{\mathrm{TN}}\left(\mathrm{mg} . \mathrm{l}^{-1}\right)$ & $5.38 \pm$ & 0.50 & $\mathrm{a}$ & $9.25 \pm$ & 1.46 & b & 3.41 & \pm & 0.21 & $\mathrm{a}$ \\
\hline $\mathrm{TP}\left(\mu \mathrm{g} . \mathrm{l}^{-1}\right)$ & $274 \pm$ & 98 & a & $900 \pm$ & 275 & b & 143 & \pm & 29 & a \\
\hline $\mathrm{K}\left(\mathrm{mg} \cdot \mathrm{l}^{-1}\right)$ & $7.6 \pm$ & 0.1 & & $9.4 \pm$ & 0.8 & & 7.7 & \pm & 0.4 & \\
\hline $\mathrm{Ca}\left(\mathrm{mg} \cdot \mathrm{l}^{-1}\right)$ & $35.5 \pm$ & 2.0 & & $42.3 \pm$ & 2.5 & & 37.8 & \pm & 1.4 & \\
\hline $\operatorname{Mg}\left(\mathrm{mg}^{-1} \mathrm{l}^{-1}\right)$ & $7.0 \pm$ & 0.4 & & $8.5 \pm$ & 0.5 & & 7.1 & \pm & 0.4 & \\
\hline $\mathrm{Fe}\left(\mathrm{mg} \mathrm{l}^{-1}\right)$ & $0.44 \pm$ & 0.06 & a & $0.19 \pm$ & 0.01 & b & 0.26 & \pm & 0.04 & b \\
\hline \multicolumn{11}{|c|}{ Dry matter of loose sediment } \\
\hline Parameter & \multicolumn{3}{|c|}{ dense } & \multicolumn{2}{|c|}{ sparse } & \multicolumn{4}{|c|}{ dead } & \\
\hline TN (mg.kg $\left.{ }^{-1}\right)$ & $13691 \pm$ & 2800 & & $18400 \pm$ & 1713 & & 17851 & \pm & 953 & \\
\hline $\mathrm{TP}\left(\mathrm{mg} \cdot \mathrm{kg}^{-1}\right)$ & $858 \pm$ & 67 & $\mathbf{a}$ & $1381 \pm$ & 152 & b & 1228 & \pm & 114 & $\mathrm{ab}$ \\
\hline $\mathrm{K}\left(\mathrm{mg} \cdot \mathrm{kg}^{-1}\right)$ & $351 \pm$ & 47 & & $420 \pm$ & 36 & & 456 & \pm & 70 & \\
\hline $\mathrm{Ca}\left(\mathrm{mg} \cdot \mathrm{kg}^{-1}\right)$ & $4559 \pm$ & 594 & $\mathbf{a}$ & $6902 \pm$ & 707 & $a b$ & 7503 & \pm & 301 & b \\
\hline $\operatorname{Mg}\left(\mathrm{mg} \cdot \mathrm{kg}^{-1}\right)$ & $509 \pm$ & 95 & & $746 \pm$ & 82 & & 904 & \pm & 113 & \\
\hline LOI (\%) & $40.4 \pm$ & 2.8 & $a b$ & $30.3 \pm$ & 2.1 & a & 48.5 & \pm & 3.6 & b \\
\hline \multicolumn{11}{|c|}{ Dry matter of solid sediment } \\
\hline TN (mg.kg-1) & $1705 \pm$ & 3 & & $3055 \pm$ & 1228 & & 2470 & \pm & 762 & \\
\hline $\mathrm{TP}\left(\mathrm{mg} \cdot \mathrm{kg}^{-1}\right)$ & $257 \pm$ & 20 & & $412 \pm$ & 167 & & 187 & \pm & 12 & \\
\hline $\mathrm{K}\left(\mathrm{mg} \cdot \mathrm{kg}^{-1}\right)$ & $96 \pm$ & 6 & & $175 \pm$ & 61 & & 87 & \pm & 23 & \\
\hline $\mathrm{Ca}\left(\mathrm{mg} \cdot \mathrm{kg}^{-1}\right)$ & $1609 \pm$ & 202 & & $3025 \pm$ & 1494 & & 3212 & \pm & 918 & \\
\hline $\mathrm{Mg}\left(\mathrm{mg} \cdot \mathrm{kg}^{-1}\right)$ & $217 \pm$ & 13 & & $330 \pm$ & 95 & & 259 & \pm & 56 & \\
\hline LOI (\%) & $12.2 \pm$ & 2.0 & & $17.7 \pm$ & 6.0 & & 6.0 & \pm & 1.3 & \\
\hline
\end{tabular}

Figures 


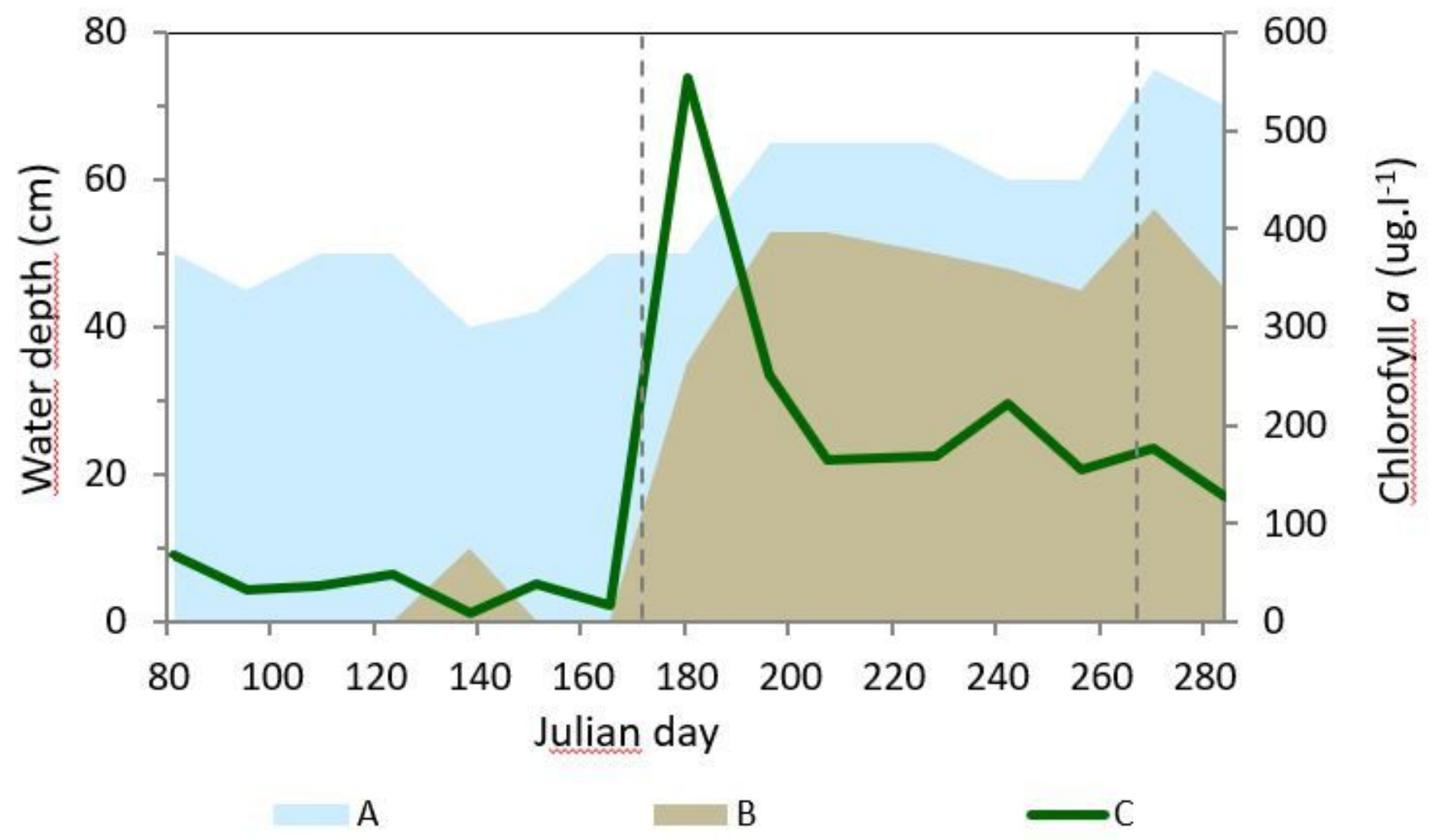

Figure 1

Seasonal course of water transparency and chlorophyll a content in the water column. The vertical lines separate spring from summer (Julian day 173) and summer from autumn (Julian day 267). A - photic zone; B - dark zone; C - chlorophyll a content. 


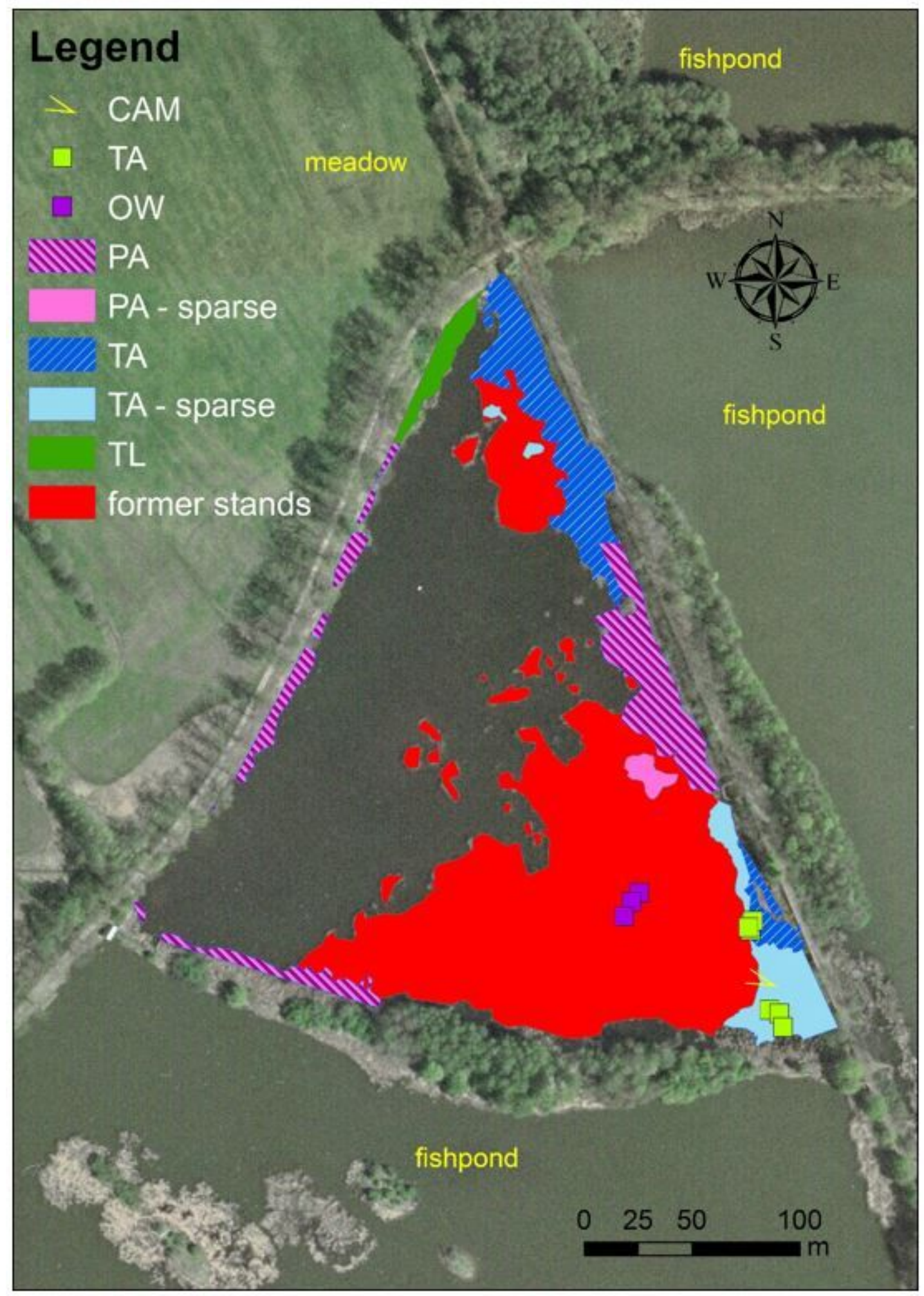

\section{Figure 2}

Vegetation map of littoral stands in 2013 plotted into the orthophoto map from 2004. CAM - camera trap, TA - stands of Typha angustifolia, OW - open water. Squares indicate positions where water and sediments were sampled. Former stands disappeared between 2004 and 2013. 


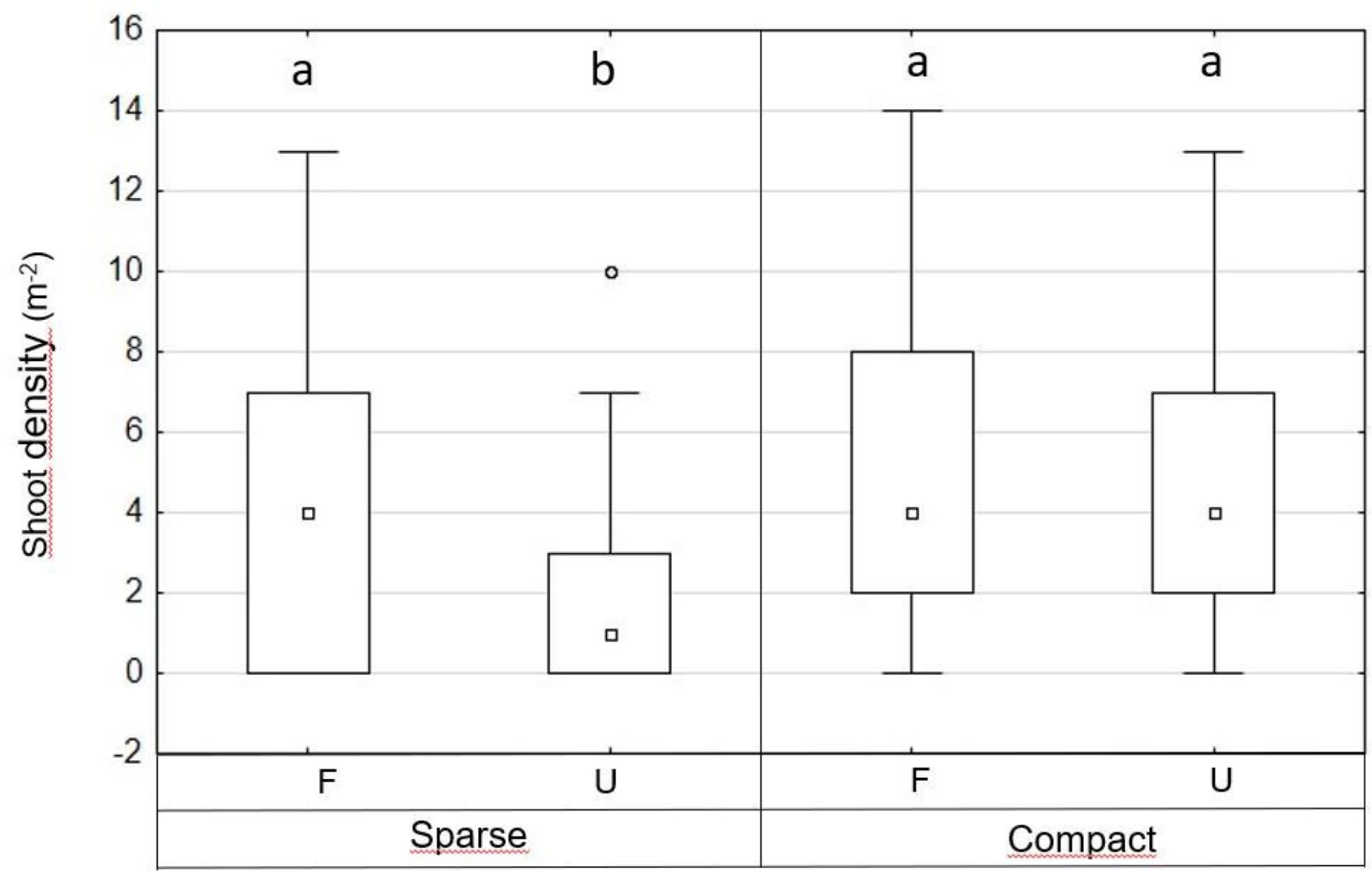

Figure 3

Shoot densities in fenced $(\mathrm{F})$ and unfenced $(\mathrm{U})$ belt transects laid in sparse and compact stands of $\mathrm{T}$. angustifolia, respectively. The plot shows medians (squares), quartiles (boxes), maximum and minimum values (whiskers), outliers and extremes (circles, asterisks). 


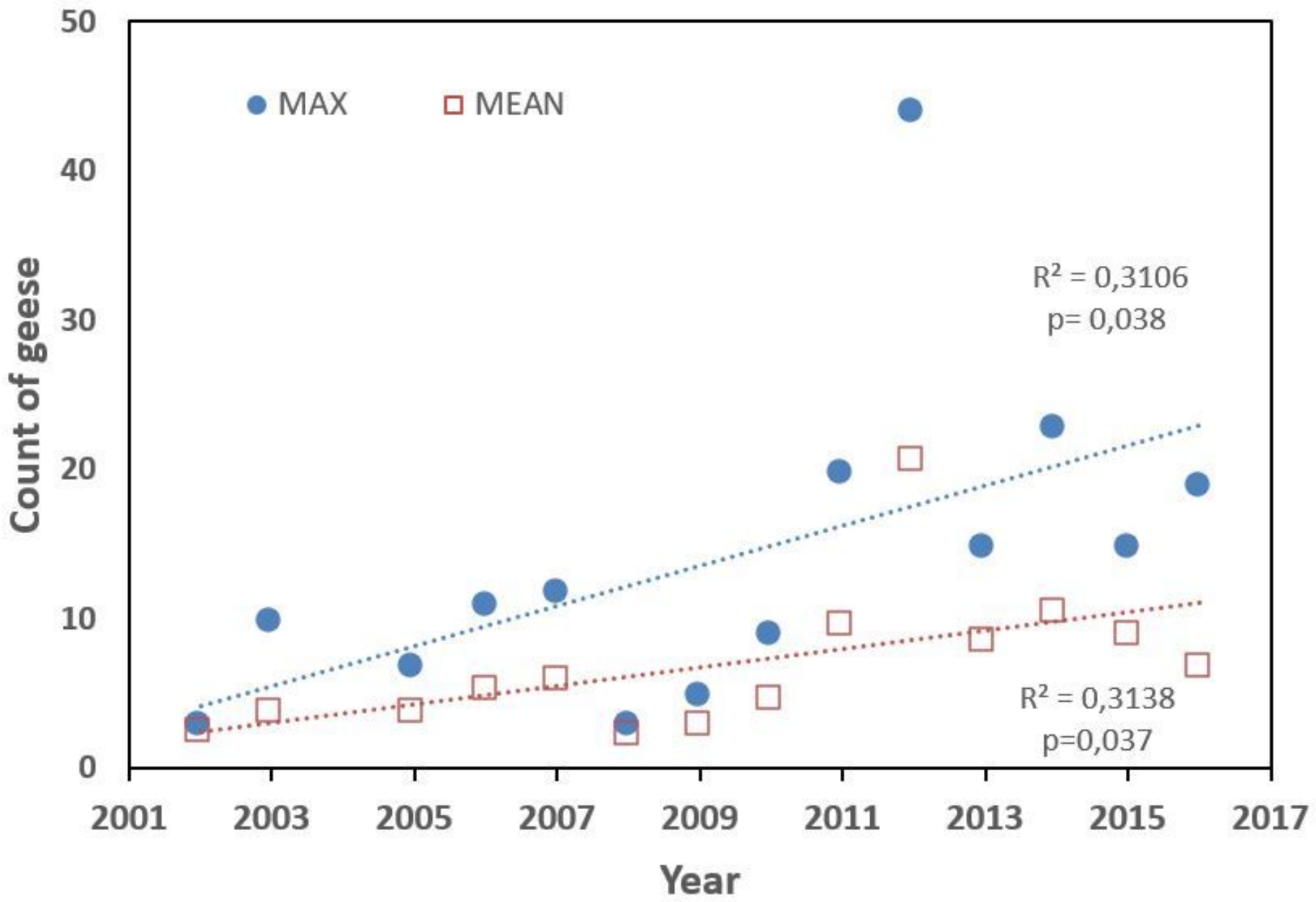

Figure 4

Geese numbers on Bažina fishpond in 2002-2016. MAX - maximum annual numbers, MEAN - mean numbers in the breeding period (March to July). Numbers. Dotted lines indicate linear regression.

\section{Supplementary Files}

This is a list of supplementary files associated with this preprint. Click to download.

- Fundingsources.docx

- Onlres1sezonnichod.pptx

- Onlres2anovaweather.pptx

- Onlres3fototabule.pptx 